\title{
A Filosofia Política de Hobbes e o Estado Absolutista ${ }^{1}$
}

\author{
Sharon Cristine Ferreira de Souza ${ }^{2}$ \\ Thiago Vieira Mathias de Oliveira $^{3}$
}

\begin{abstract}
Resumo
Desenvolve-se uma análise trazendo, principalmente, um apanhado histórico e uma descrição sistemática a respeito da vida e obra do contratualista Thomas Hobbes, bem como sua filosofia, suas influências, delineando o porquê das concepções e conceitos trazidos em seus escritos, seus objetivos e como o Absolutismo, na posteridade, desemboca no modelo de Estado Liberal, com a sede por direitos individuais observadas na crescente burguesia.
\end{abstract}

Palavras Chave: Hobbes; Contratualismo; M utualismo.

\section{Introdução}

O período absolutista é marcado pela figura do soberano, outrora erigida ao status de representante personificado na terra de uma existência superior e divina, o qual se torna um fator necessário à garantia de preservação de bens (propriedade) e direitos individuais, ideais que tiveram seu advento com a burguesia nascente -crepúsculo da Idade M édia.

Os indivíduos, então, saem do estado de natureza, onde a posse é precária, bem como a integridade física e a paz, para, mediante um pacto, um acordo entre determinado número de pessoas, haver a união para um convívio sob a égide de um Estado civil, dirigido por leis claras cujo objetivo era garantir a auto-preservação e a manutenção de bens.

A conservação desse Estado Civil, com os limites impostos à plena liberdade humana por meio de regras estabelecidas em prol de uma convivência harmônica e pacífica e de uma estabilidade social, ficaria adstrita ao arbítrio de outrem, seja o poder do

\footnotetext{
${ }^{1}$ Este artigo é resultado de estudos realizados no projeto de pesquisa "Estado e relações empresariais: diálogos filosóficos e jurídicos diante da regulação estatal sobre a ordem econômica nacional" do Curso de Mestrado em Direito Negocial da Universidade Estadual de Londrina.

${ }^{2}$ Especialista em Direito do Estado e Mestre em Direito Negocial, ambos pela Universidade Estadual de Londrina.

${ }^{3}$ Mestre em Direito Negocial pela Universidade Estadual de Londrina e Professor da Universidade Luterana do Brasil - ULBRA-Ji-Paraná.
}

REVISTA dE DIREITO PÚBLICO, LONDRINA, V, 4, N. 2, P. 16-36, SET./ DEZ. 2009. 
soberano, de acordo com a concepção de Hobbes, seja do poder legislativo, posteriormente defendido por John Locke.

$\mathrm{Na}$ visão antropológica hobbesiana, extremamente negativista e pessimista, os seres humanos egoístas e mal intencionados deveriam ser governados por um poder político absoluto localizado acima desse pacto - e de todos os outros indivíduos (seus súditos) -, sendo assim um legislador pleno e cumpridor dessas leis a fim de manter a ordem, apaziguar os ânimos, fazer respeitar a propriedade, a vida e os contratos.

Faz-se necessário verificar, portanto, na obra de Hobbes todas essas concepções que delineiam o Estado moderno absolutista, desde sua contextualização histórica, bem como influências de suas obras, para, posteriormente, entender como surgiu, no decorrer da história, o modelo de Estado Liberal preconizado por Locke.

\section{Contextualização histórica da obra de Hobbes}

Hobbes nasce em 1588 na Inglaterra e falece em 1679. Era de família pobre de nenhuma tradição intelectual e teve seus estudos patrocinados por um tio, sempre pouco atraído pelo aprendizado escolástico. Como pupilo teve uma formação inicial de contato com os clássicos, com a literatura - em 1629 traduziu Guerra do Peloponeso, uma análise política e moral deste conflito por Tucídidas -, com a história e aprendeu latim e grego.

Já como preceptor, aprofundou o conhecimento dos clássicos e viajou à Europa, quando teve contato com Francis Bacon, do qual foi secretário e de cujo empirismo/experimentalismo sofreu influência, com René Descartes, com quem polemizou escrevendo as objeções à Terceira Meditação, mas sem deixar de ser influenciado por seu racionalismo, assim como também Euclides (Elementos de Geometria) e Galileu influíram na construção de seu conhecimento.

Estas experiências marcaram a contribuição de Hobbes para a superação da escolástica medieval, em relação à qual sempre teceu críticas. Neste sentido, a inovação da filosofia de Hobbes abriu espaço para a convivência entre dois extremos: empirismo e racionalismo. Construiu sua filosofia política a partir da natureza, à qual sempre voltava ao percorrer um trajeto em que o real, isto é, os fatos da experiência, eram reduzidos a elementos simples, a conceitos e definições, a fim de que se pudesse utilizá-los numa demonstração capaz de recompor as realidades concretas. Ressaltava que tal demonstração

ReVISTA DE Direito Público, LondRINA, V, 4, N. 2, P. 16-36, SET./ DEZ. 2009. 
não era dedutiva, por isso não era uma demonstração no sentido rigoroso da palavra, mas consistia em cada um encontrar-se em si mesmo - a natureza do homem.

Por isso sua teoria do conhecimento faz uma retrospectiva analítica do desenvolvimento da consciência desde a sensação até as diversas ciências, passando pelas noções de signo e linguagem. Hobbes adota como modelo de sua empreitada a ciência, demonstrativo que tem como pontos de partida axiomas - verdades evidentes, verdades em si mesmas -, captados intuitivamente, baseados em definições a partir das quais são demonstradas outras proposições chamadas teoremas.

Em sua obra Hobbes tem pretensão de fundar uma rigorosa ciência ética/política ou filosofia moral, não separando nitidamente ciências da natureza demonstrativas e ciências do homem, não demonstrativas ${ }^{4}$. Para Hobbes, a política é capaz de se transformar numa ciência demonstrável devido à mesma razão pela qual a geometria pode: são os indivíduos que criam as figuras sobre as quais se raciocina; igualmente são também os indivíduos quem criam o Estado (POUSADELA, 2006, p. 358).

Também foi muito influenciado pelos movimentos sociais e políticos que presenciou na Inglaterra, apesar de nunca ter sido um "ativista político, um homem de partido ou um conselheiro de príncipe", mas um erudito. Suas teorias sobre o homem e sobre o Estado formuladas no Leviatã e em Sobre o Cidadão, inserem-se num processo histórico de lutas sociais e econômicas bem definido: os conflitos entre poder real e poder do Parlamento na Inglaterra do século XVII. Hobbes parte de um problema real de seu tempo para suas formulações: a Inglaterra que se constituía uma monarquia constitucional via-se ameaçada pelas discórdias religiosas e políticas entre os dois poderes - Coroa e Parlamento - e pela disputa em torno da divisão dos poderes.

Defende a unidade contra a anarquia - retorno do homem ao estado de natureza e o que mais teme não é a opressão que deriva do excesso de poder, mas a insegurança que resulta, ao contrário, da escassez de poder. O Leviatã é a síntese do hobbeanismo. É fruto da combinação de um espírito mecanicista juntamente com as obsessões de um coração cheio de temor, ávido de paz tanto para si próprio, como para seu país (CHEVALLIER, 1973, p. 67).

\footnotetext{
${ }^{4}$ Mas Hobbes não consegue se "libertar" completamente das influências baconianas. Com base na consideração do Estado, ele divide todo campo da filosofia em duas partes: a filosofia natural e a filosofia civil: a primeira tem por objeto a definição de obra da natureza e a segunda trata do que se constitui pela vontade humana mediante convenções e pactos entre os homens.
} 
Em 1640, colocou-se como defensor do rei Carlos I (1600-1649), ameaçado pela revolução liberal e contra o parlamento. Para tanto escreve Natureza Humana e Sobre 0 Corpo Político, que circulam em manuscritos e só viriam a ser publicados em 1650. Tais escritos o fazem exilar-se em Paris por onze anos, com medo dos movimentos antimonárquicos. Lá, em 1642, publica Sobre o Cidadão, ano em que eclode a Guerra Civil na Inglaterra. Em 1651 publica Leviatã, já quando a dissolução do Estado inglês levou ao extremo da guerra civil ${ }^{5}$ e ao regicídio. Por essa publicação é banido da corte Inglesa, já exilada em Paris.

Em 1652 retorna definitivamente à Inglaterra, dominada pela ação de Cromwell (1599-1658), que comandara a revolução liberal de 1642, ocasião em que já estava publicado o Leviatã, motivo pelo qual foi acusado de coadunar com o novo governo, fruto da revolução que condenara anteriormente. Além de tudo, provocara a ira das monarquias de toda Europa, porque justificava um poder alcançado mediante a conquista e não como fruto de uma dádiva divina. Os argumentos da própria obra e o restante da vida de Hobbes negaram isso, a ponto de ter sido acolhido por Carlos II, quando da Restauração (1660) - sua obra é interpretada como apologia à Restauração. Publica em 1654 Sobre o Corpo e em 1658 Sobre o Homem. Em 1660 ocorre a restauração dos Stuart, com quem Hobbes se reconcilia.

Conjunto da obra de Hobbes leva à conclusão de que ele concebeu seu projeto de pesquisa como sendo dividido em: corpo - matéria da física -, homem - domínio da psicologia - e cidadão - domínio da política. Esta última subdivisão de seu projeto, composto antes das outras, idealizado quando a Inglaterra estava às vésperas da guerra civil, teve sua forma verdadeiramente acabada principalmente com a obra Leviatã. Esta apresenta um quadro completo da filosofia hobbesiana, versando sobre todos os problemas filosóficos que se Ihe apresentavam, propondo ao mesmo tempo, uma teoria do conhecimento, uma teoria política, uma teoria jurídica e uma teologia.

\section{Filosofia política Hobbesiana}

\footnotetext{
${ }^{5}$ Carlos I reinava desde 1629 sem convocar parlamentos, mas se vê sem recursos para enfrentar seus súditos rebeldes da Escócia, presbiterianos revoltados contra as tentativas monárquicas de lhes impor uma organização episcopal. É obrigado a convocar o Parlamento, único poder com autoridade para votar impostos. Este reunido se recusa a este feito e é dissolvido por Carlos I, que meses depois é obrigado a convocar novo Parlamento.
} 
Observa-se, então, a forte influência racionalista em Hobbes, que pretendia estabelecer as definições de cada palavra em sua obra com a pretensão de fazer ciência, ainda também, criticando outros autores que usavam as palavras levianamente, isto é, no sentido de anteriormente não estabelecerem esse pacto semântico e, portanto, deixando os leitores e estudiosos sem entender ao certo o sentido e a significação que se pretendeu dar aos escritos.

Dessa forma, consoante exposto, Hobbes traz uma série de definições, que serão usadas no decorrer da obra. No capítulo XII começa a falar sobre religião, sobre sua visão a respeito de Deus, cuja discussão será melhor abordada posteriormente - inclusive com a explicação sobre a capa do livro. Finalmente ele começa a construir o seu raciocínio em torno do denominado "estado de natureza".

Para Hobbes, a causa de tudo está na diversidade do movimento. 0 ponto de partida da ação humana e, conseqüentemente da ação moral e política. É o esforço, o movimento, ou seja, uma provocação para que se aproxime do que se the agrada ou para que se retire do que se the desagrada. Chama este esforço de desejo e, posteriormente, de "vontade", o último apetite na deliberação que regeria a atividade psicológica, as paixões úteis ou não ao homem em sua vida cotidiana. Nesta mesma ordem de idéias, a liberdade reduz-se à ausência de tudo que impede a ação e que não está contido na natureza e na qualidade intrínseca do agente.

"Estado de natureza" é o modo de ser que caracterizaria o homem antes de seu ingresso no estado social - estado civil -, na ausência de um poder comum que imponha uma ordem. Hobbes concebe a natureza como uma grande máquina, cujo funcionamento 0 homem é capaz de entender - quando compreende as leis que regulam seu mecanismo -, podendo imitar, recriar, aperfeiçoar e acrescentar potência a ela, inclusive construindo outras máquinas em seu interior, dentre elas o Estado (BOBBIO, 1991, p. 31). Por isso não considera a criatividade e inventividade humana obras da natureza, mas produtos do homem. Entre esses produtos está a vida associada.

A concepção hobbesiana de estado de natureza se distancia da maior parte dos filósofos políticos - Aristóteles, Locke, Kant. Neste estágio da vida humana, não há qualquer restrição artificial da liberdade e a vontade manifestada em cada um se verte em seguida no movimento para conquista deste bem, o que faz da "propriedade" apenas um domínio - que 
não é um direito - do indivíduo que é capaz de consegui-la e mantê-la, só pertencendo a cada um enquanto puder conservar a posse ${ }^{6}$. Não importa se para isso se tenha que atacar ou defender, num perpétuo e irrequieto desejo de poder e mais poder (PAVÃO, 2000, p. 395), não porque o homem seja simplesmente mau, um lobo de outro homem, mas pelo fato de não poder, por si mesmo, garantir o poder e os meios para viver bem, que atualmente possui sem adquirir mais ainda.

Para todo homem, o outro é concorrente e ávido pelo poder, o que consiste em sua condição de felicidade e instrumento mediante o qual seus desejos se realizam (CHEVALLIER, 1973, p. 69). Aí reside o real problema do poder para Hobbes: ele é definido como 0 conjunto dos meios, como riqueza, reputação, amizades, empregados, para obter uma aparente vantagem futura, e sua noção genérica compreende, pelo menos, duas coisas: bens econômicos e força física. Por isso, considera uma inclinação geral de todo ser humano um perpétuo e incessante desejo de poder cada vez maior que só cessa com a morte. E o desejo de poder gera um estado permanente de guerra durante o tempo em que os homens vivem sem um poder comum que os mantenha subjugados.

A descrição do estado de natureza não é a descrição do homem selvagem no estágio primitivo da humanidade, mas uma simulação negativa da ordem social, uma pura hipótese da razão - sociedades primitivas, no caso de guerra civil, nas sociedades internacionais - sem a presença do Estado, que administraria e não aboliria o conflito entre os homens na deficiência ou inoperância do Estado.

Mesmo admitindo que algumas sociedades primitivas tenham vivido em estado de natureza, as formas de estado de natureza que interessam a Hobbes são as que ainda subsistem em seu tempo: a sociedade internacional e 0 estado de anarquia originado pela guerra civil. Sobretudo o segundo. (BOBBIO, 1991, p. 36)

A guerra de todos contra todos é na verdade a guerra civil, pior do que qualquer outra, conquanto na guerra externa há possibilidade de existir alguma produtividade, podendo servir de excelente meio para acumulação de metais preciosos (RIBEITO, 2006, p. 33). 0 estado de natureza não diz respeito a uma anterioridade história, mas a uma precedência lógica em relação à vida social, uma descrição de como os homens viveriam sem o estado civil. Não há que se pensar em oposição entre homem natural e homem que vive

\footnotetext{
${ }^{6}$ Para Locke, ao contrário, a propriedade é um direito natural anterior ao Estado.
} 
em sociedade, haja vista que, para Hobbes, a natureza do homem não muda conforme 0 tempo, história ou vida social (RIBEIRO apud PAVÃO, 2000, p. 396).

Para Hobbes, todos os homens são naturalmente iguais - no estado de natureza - , dotados de igual força, aptidões intelectuais ou meios necessários para se igualar nesses dois aspectos - igualdade quanto à capacidade para se alcançar os fins almejados. Mesmo se constituindo fato a igualdade quanto à capacidade humana. Admite a possibilidade de existência de uma desigualdade natural, razão por que todos os homens, por sua vontade e não naturalmente, buscariam se igualar aos demais - igualdade pretendida. Neste sentido a igualdade seria menos um dado objetivo do que elemento subjetivo, haja vista os homens se considerarem a si mesmos e aos outros (PAVÃO, 2000, p. 391). 0 homem considera-se igual porque, apesar de reconhecer as qualidades do outro, admite que poucos são melhores do que ele. Isso porque os homens vêem as qualidades dos outros de longe, enquanto as suas de perto.

A demanda pela igualdade geraria um conflito, porquanto no estado de natureza não existiriam leis positivas para regular as expectativas de igualdade. Por isso o recurso à violência generalizar-se-ia na inexistência de outras garantias de segurança que não a força, cada qual desejando o mesmo bem que o outro, em condições de escassez de bens, e elaborando novos meios de submissão do próximo, como forma de elidir sua potencial desigualdade em relação a ele: uma disposição inevitável para a guerra. No estado de natureza, quando as leis positivas ainda não foram introduzidas, não há critérios para diferenciar o que é de um do que é do outro, fazendo com que todo homem tenha direito de se apropriar de tudo o que cair em seu poder.

Para Hobbes a inexistência do Estado gera um ambiente intolerável cuja característica maior consiste no "medo" e desconfiança que surge necessariamente da premissa de igualdade entre os homens, quanto à sua capacidade e quanto à esperança de satisfação de seus objetivos. 0 estado de natureza não é apenas o estado de conflito violento, mas também a situação na qual a calmaria é precária e a paz momentânea, sendo apenas assegurada pelo temor recíproco. A causa principal da segurança é a falta de um 
poder comum, só instituído com o surgimento do Estado7. "Disto nasce um estado permanente de desconfiança recíproca, que leva cada um a se preparar mais para a guerra e, quando necessário, a fazê-la - do que para a busca da paz" (BOBBIO, 1991, p. 34).

Porque os homens compartilham entre si da insegurança generalizada, colocandose em disposição para a guerra, o que revela que Hobbes não defende nem uma natureza sociável para o homem - Aristóteles -, nem uma natureza anti-social - o lugar comum da interpretação da "guerra de todos contra todos" -, mas uma desconfiança radicalizada e racional. A disposição para a desconfiança, para a competição, enfim, para a guerra, não quer dizer que o homem seja mau por natureza, mas que deseja apenas, por meio de cálculos e desejos, buscar o melhor para sua conservação. 0 indivíduo entra em sociedade somente quando a preservação da vida e a paz estão ameaçadas. "A natureza não colocou no homem o instinto da sociabilidade; o homem só busca companheiros por interesse, por necessidade; a sociedade política é o fruto artificial de um pacto voluntário" (CHEVALLIER, 1973, p. 70).

Os homens são levados a estabelecer, unicamente entre os membros do grupo, um "contrato" numa renúncia/transferência mútua do "direito a tudo", de uma parcela - bem grande - de liberdade/poder/prerrogativas para entregá-la a um poder comum, a um soberano - monarca ou assembléia - encarregado de garantir a paz, a segurança e a ordem sem os quais o homem não poderia estabilizar minimamente as expectativas de seu estar no mundo, mas também o gozo das satisfações legítimas da vida.

\section{Sobre o pacto}

O contratualismo é uma doutrina que reconhece como origem ou fundamento do Estado uma convenção ou estipulação entre seus membros ${ }^{8}$. Foi subjugado na Idade M édia pela doutrina da origem divina do Estado, mas ressurge na Idade Moderna com 0 jusnaturalismo como libertação em relação aos costumes e tradições políticas do M edievo, tanto no sentido de defender o poder absoluto - Hobbes e Spinoza - quanto para demonstrar a tese do poder político limitado - Grócio, Pufendorf, Locke, Rousseau, Kant.

\footnotetext{
${ }^{7}$ Hobbes não faz qualquer referência à célula familiar, nem à família alargada, nem aos corpos intermediários existentes entre 0 Estado e 0 indivíduo, velhos resquícios da Idade Média. Hobbes refere-se a estas instituições no Leviatã apenas para criticá-las, considerando-as pequenas repúblicas.

${ }^{8}$ Já era defendida pelos sofistas, por Epicuro, Canéades.
} 
Como ponto comum em todos os contratualistas, tem-se que o contrato não é somente um pacto de governo que rege as relações entre o governante e governados, mas um acordo tácito que fundamenta toda comunidade, que leva os indivíduos a conviver, participando dos bens, serviços e leis vigentes na comunidade (ABBAGNANO, 2000, p. 206). Em Rousseau o contrato ganha linhas específicas, pressupondo indivíduos que possuem direitos individuais e que os renuncia, para adquirir outros com o contrato.

Para Hobbes, 0 pacto se estabelece entre os indivíduos singularmente considerados, entre os membros de um conjunto de indivíduos isolados - e não entre os indivíduos já estabelecidos num povo - e o destinatário da submissão de cada um, que será o soberano. A vontade única desse terceiro absolutamente estranho a este contrato substitui a vontade de todos. Hobbes ensina que, por um só e mesmo ato, os homens naturais constituem-se em sociedade política e se submetem a um soberano, mas não estabelecem contrato com este, mas entre si.

É entre si que renunciam a todo direito e toda liberdade nocivos à paz em proveito do soberano. Hobbes foge do conflito entre direitos da multidão, erigida em "pessoa", em "povo", e o soberano, órgão da personalidade do Estado. "Longe de enfraquecer o poder, Hobbes o fortalece de maneira singular". (CHEVALLIER, 1973, p. 72) Por isso, para que uma multidão converta-se em povo é necessária a saída do estado de natureza e a atribuição do poder comum a um soberano.

Rousseau defende um pacto estabelecido entre o povo e os governantes. Esse pacto estabeleceria a submissão dos governantes, assim como de todos os cidadãos à vontade geral, que se volta para o bem comum. Para Hobbes, o poder soberano contém as vontades e dirige as ações para o proveito comum, produzindo a reunião das vontades particulares numa única vontade. Assim, ele entende que, uma vez estabelecido o soberano, este encarna a força da coesão apta a transformar a multidão num povo consciente. Além disso, de um povo detentor do poder soberano não se origina o Estado. 0 pacto entre povo e soberano, se vier a ocorrer, é, na realidade, um pacto entre o titular da soberania e a pessoa - ou as pessoas - a quem se pede o exercício desta soberania. Portanto, observa-se que um pacto deste tipo nada tem a ver com o pacto de união que dá origem à sociedade civil (BOBBIO, 1991, p. 46). 
Em favor da irrevogabilidade do contrato e do poder soberano, Hobbes nega que um dos dois contratantes seja o povo, pois bastaria o acordo da maioria para que o contrato pudesse ser rescindido. Mas, quando os contratantes são, indistintamente, todos os membros da sociedade civil, como multidão e não como povo, então a rescisão do contrato pode ocorrer apenas mediante a unanimidade - e não a maioria -, além do consenso do próprio soberano, terceiro diante do qual as partes estão reciprocamente obrigadas (BOBBIO, 1991, p. 44). 0 poder soberano apóia-se na obrigação por parte do cidadão em face dos demais cidadãos e do cidadão em face do soberano. A única exceção à manutenção do contrato e à preservação do poder do soberano é a falha deste último na manutenção da segurança, paz e prosperidade material dos súditos.

\section{Razão e paixão: a passagem para o Estado Civil}

Para Hobbes não é possível afirmar o conflito entre os homens no estado de natureza exclusivamente em razão da escassez de bens e a conseqüente luta de classes, como na perspectiva materialista de Marx e Engels. Da premissa da igualdade, segundo Hobbes, enraizada na natureza humana, faz-se impossível afirmar que não restariam homens diferentes, tendo em vista os desejos coincidentes de objetos que só podem ser gozados por um deles, o que aconteceria mesmo com a extinção das classes sociais. Além disso, contribuiriam para o conflito entre os homens o desejo humano de mais e mais poder, uma tendência natural do homem ou simplesmente o desejo de glória, que subsistiriam mesmo se existissem bens disponíveis para todos.

Necessário salientar que em Hobbes não existe oposição forte entre "paixão" e "razão" no estabelecimento, pelo homem, do estado civil com sua saída do estado de natureza ${ }^{9}$, isto é, no estado de natureza o homem seria governando por suas paixões ${ }^{10}$ e no estado civil guiar-se-ia por sua razão. Mas só tem sentido o movimento de ingresso no estado civil se o homem já for guiado pela razão. Tanto paixão como razão desempenham papel decisivo na saída do homem do estado de natureza, uma vez que a razão é a

\footnotetext{
${ }^{9}$ Apesar de que em algumas passagens do Leviatã e em Do Cidadão é possível tirar essa conclusão: “(...) fora da Cidade campeia a força das paixões, a guerra, o medo, a pobreza, a vergonha, a solidão, a barbárie, a ignorância, a brutalidade; na Cidade reina o poder da razão, a paz, a segurança, a riqueza, a beleza, a convivência, compostura, a ciência, a amizade" (De Cive, cap. X, par. 1).

${ }^{10} \mathrm{M}$ uitas das paixões humanas o conduzem para paz, como o temor.
} 
capacidade de calcular os meios adequados para se atingir aquilo que as paixões indicam, como fim desejável, num cálculo de conseqüências, sugerindo para tanto as adequadas leis da natureza. A razão faz parte da natureza humana do mesmo modo que qualquer faculdade ou sentimento, mas não é inata como a sensação ou a imaginação; é adquirida com a atividade, segundo um jogo de denominações corretas. A razão não se trata de conhecer a essência das coisas, mas a faculdade de raciocinar, entendido o raciocínio como um cálculo mediante o qual, dadas certas premissas, extraem-se necessariamente certas conclusões raciocínio silogístico.

A razão faz com que o homem aja não só obedecendo a essa ou àquela paixão, mas também seguindo o próprio interesse. A razão serve às paixões - como o medo recíproco -, estabelecendo um arranjo voltado para a sociabilidade a partir da auto-conservação. Sem os incentivos passionais, a razão não move coisa alguma. "[...] a razão é, em si mesma, a modalidade muito peculiar de paixão conservadora" (SOARES apud PAVÃO, 2000, p. 407). 0 homem que sai do estado de natureza e ingressa no estado civil não pode ser entendido como o indivíduo passional que se converteu em racional. 0 indivíduo, tanto no estado de natureza como no estado civil, é o mesmo: um ser desejoso e calculador, um ser de paixão e de razão que percebe que, para seres iguais como os homens, o estado de guerra não pode terminar pela vitória de um indivíduo isolado sobre o outro. Apenas sob a autoridade política pode-se proteger o indivíduo da intensa instabilidade vivida no estado de natureza. Isso mostra que Hobbes não confiava tanto assim na razão humana, caso contrário, não apresentaria ao homem como solução de seus problemas um poder tão irresistível.

A condição preliminar para que o homem saia do estado de natureza é o acordo de todos com a instituição de uma situação tal que permita a cada um estabelecer-se racionalmente com a segurança de que os demais também o farão, o que equivale a estipular um acordo preliminar que vise instaurar as condições de preservação da vida. Para que os homens vivam em paz não basta a ação da razão; faz-se necessário o Estado e as leis civis - neste aspecto, Hobbes vincula a existência do Direito à existência do Estado. Também refuta a simples associação de pessoas que buscam um fim comum como ato fundador do Estado, pois uma sociedade fundada dessa forma não asseguraria a observância das regras de que ela própria necessita para desempenhar sua função. 
Mas o pacto, sendo artificial e precário, não é suficiente para assegurar a paz, pois além de sempre existirem pessoas que se julgam mais sábias do que as demais, o homem tem uma vontade quase inevitável de violar as leis para obter as vantagens do estado de natureza, podendo desencadear uma guerra civil na busca do poder só para elas. Para que todos vivam em paz não basta a orientação da razão; é preciso um acordo de todos para sair do estado de natureza e a instituição de uma situação tal que permita a cada um seguir os ditames da razão com a segurança de que os outros farão o mesmo. Só o contrato não alcançaria este objetivo. Por isso se faz necessário a instituição de um poder tão irresistível que torne desvantajosa a ação contrária, ou seja, é preciso que os homens submetam sua própria vontade à de um único homem ou à de uma assembléia determinada - a uma única pessoa, física ou jurídica, que detém a Administração, a Justiça a Legislação e a força militar -, pois o poder só poderia corresponder a sua finalidade se exercido de forma absoluta, conduzindo o pacto, necessariamente, ao absolutismo.

\section{Absolutismo}

Assim, o absolutismo não deriva de um direito divino, mas sim do pacto, e a existência do Direito - leis civis - vincula-se à existência do Estado. Embora manifeste sua preferência por um rei absoluto, Hobbes reconhece a legitimidade de outros tipos "puros" de governo - estão reunidos numa mesma pessoa o Legislativo, o Executivo e o Judiciário porque os vários poderes que cabem ao soberano são tão estreitamente ligados um ao outro, tão interdependentes, que não podem deixar de pertencer a uma só pessoa. A justificativa para a preferência do governo monárquico está na antropologia humana: todo homem e, por conseguinte, todo governante, pensa no seu interesse pessoal. Portanto, interesse público só é possível na monarquia (CHEVALLIER, 1973, p. 73).

Hobbes admite um Parlamento com papel consultivo e a assessoria ao monarca por um conselho de ministros, mas não admite os governos mistos - segundo a orientação aristotélica, o poder de fazer leis é atribuído a uma grande assembléia democrática, o poder de julgar a uma outra assembléia e a tarefa de cuidar para que as leis sejam executadas a uma terceira - exercido por um homem qualquer - como na monarquia constitucional - ou dividido entre vários soberanos, principalmente a partir das três formas aristotélicas: monarquia, aristocracia e democracia, ou dividindo poder espiritual de poder temporal -

ReVISTA DE Direito Público, LondRINA, V, 4, N. 2, P. 16-36, SET./ DEZ. 2009. 
pois a divisão de poder provocaria competições que comprometeriam a paz. Governar significa constituir o Estado - que conseguiria congregar esse poder irresistível - sobre bases tão sólidas que se torne impossível sua dissolução, principalmente por meio da guerra civil.

No contexto da sociedade civil, a liberdade de cada indivíduo verte-se em toda ação do soberano que é simultaneamente também a ação de cada súdito, o qual pode, por conseguinte, ser considerado seu autor, a tal ponto que a liberdade sempre é a liberdade do Estado, ou seja, a ordem política é a única detentora da liberdade à qual os homens aspiram. A liberdade assegurada ao indivíduo pelo soberano é a ausência de obstáculo exterior aos desejos do homem. A lei civil é um obstáculo exterior e por isso liberdade do súdito, em Hobbes, significa prática unicamente dos atos que a lei não proíbe - é o germe do princípio da legalidade atribuído normalmente aos liberais.

0 contrato tem a função de instituir um poder soberano11, consistente num poder acima das partes, que se consubstancie em pessoa - física ou jurídica única - denominado de soberania. A soberania deve ser exercida sem limites exteriores. No estado de natureza, as várias relações intersubjetivas que se estabelecem são relações de poder de diferentes configurações. Já no estado civil, as relações de poder que se estabelecem são sempre bem definidas: existe um detentor único do poder político, o Estado, e os súditos, indivíduos que a esse poder se sujeitam.

No estado de natureza não há súditos e soberanos, ou melhor, cada um é soberano ou súdito conforme a situação em que se encontre de fato, podendo ser ora o mais poderoso dos soberanos de direito, ora o mais miserável dos súditos de fato. No estado civil, depois do pacto de união, o soberano é soberano e o súdito é súdito (BOBBIO, 1991, p. 46).

Hobbes aperfeiçoa a tese de Maquiavel e defende que o poder político não é um simples fenômeno de força, mas uma força institucionalizada, canalizada para o direito positivo, construindo a primeira teoria moderna do Estado.

\footnotetext{
${ }^{11}$ Predominaram na Inglaterra antes e depois de Hobbes, teorias, fundamentadas principalmente em Locke, acerca da limitação do poder do Estado, que deram origem à corrente de pensamento político do "constitucionalismo", predominante no Brasil desde o final do século XIX. Os defensores da soberania limitada afirmam que a transferência é parcial porque entre os direitos que o homem tem no estado de natureza, alguns são inalienáveis. Hobbes, ao contrário, afirma que a transferência é quase total, só restando ao indivíduo que passou a fazer parte do Estado o direito à vida - a única justificativa para eventual desobediência civil.
} 


\section{As leis da natureza e as leis civis}

A razão serve ao homem na forma de regras prudenciais do tipo hipotéticas - para o Direito, normas abstratas e gerais - a que Hobbes chamou de leis naturais, não absolutamente leis no sentido de um comando de uma pessoa dotada de autoridade, porém, leis que obrigam em foro interno, não em foro externo, haja vista no estado de natureza não ser assegurada a observância de regras de prudência que determinado indivíduo está disposto a observar.

O direito de natureza, ou jus naturale, é uma liberdade de que dispõe o homem para usar de seu poder sem nenhuma interferência externa, de modo a agir de acordo com seus próprios julgamentos acerca do que seja adequado, visando à manutenção e proteção de sua vida. A lei de natureza - lex naturalis - e o direito de natureza são inconfundíveis. Aquela obriga uma ação ou omissão e este, como já dito, consiste numa liberdade para uma ação ou omissão.

No estado de natureza as leis existem, ou seja, são válidas, nas não são eficazes, isto é, não se garante sua obrigatoriedade e sua observância - para o Direito, coerção. Todas essas regras prudenciais são subordinadas a uma primeira regra, que Hobbes chama de fundamental, qual seja, a conservação da vida ${ }^{12}$. As leis da natureza são fruto da razão ou da paixão humana e impulsionam o homem a sair do estão de natureza.

A primeira lei da natureza seria o preceito de ser mais compensatório viver no estado civil do que no estado de natureza, por isso o homem deveria se esforçar para manter a paz e seus benefícios, entre eles, a auto-conservação, ou seja, o esforço de cada homem pela convivência pacífica e, só no caso de não alcançá-la, usar de seus próprios poderes - direito de natureza - para se defender. A primeira lei da natureza resume numa fórmula simples as demais leis da natureza com a fórmula: "não façais aos outros o que não quereis que vos façam. Por conseguinte, concordai em renunciar ao direito absoluto sobre todas as coisas" (CHEVALLIER, 1973, p. 70). Em outras palavras, "é proibido ao homem fazer o que pode destruir a sua vida ou privá-lo dos meios para conservá-la ou omitir sua proteção".

${ }^{12}$ De certa forma Hobbes serve de inspiração para Kant e, posteriormente, à construção kelseniana do ordenamento de jurídico.

ReVISTA DE Direito Público, LondRINA, V, 4, N. 2, P. 16-36, SET./ DEZ. 2009. 
Nesta linha, vê-se surgir a segunda lei da natureza, que preceitua que cada homem renuncie a mesma porção de liberdade que igualmente todos os outros homens o fazem, em favor da paz, porquanto do contrário, se todos mantiverem-se inteiramente livres para agir segundo seu próprio entendimento, subsistirá o conflito entre os homens ${ }^{13}$. Consoante à segunda lei da natureza o homem no estado civil deve renunciar ao "direito a tudo" de que desfrutava no estado de natureza para viver uma limitação à plena liberdade em nome dos benefícios da paz.

Não submetido a qualquer lei civil, o soberano absoluto é a própria fonte legisladora, a qual concentra em suas mãos todos os poderes, e a obediência a ele deve ser total, tudo para que haja a possibilidade de ser assegurada a paz. Hobbes desembaraça-se da tese de que o soberano está submetido ao direito positivo com o velho argumento de que ninguém pode obrigar a si mesmo, porque quem obriga a si mesmo poderia desobrigarse conforme seu próprio arbítrio, já que as leis civis são feitas pelo soberano ${ }^{14}$. (BOBBIO, 1991, p. 48)

O soberano somente deve submeter-se às leis da natureza. Daí surge uma controvérsia ainda inconclusa hoje: os indivíduos atribuem ao soberano os poderes para que as leis naturais tornem-se leis civis - dar obrigatoriedade às leis naturais - ao mesmo tempo em que cabe ao soberano, e somente a ele, estabelecer, por meio das leis civis, o que é direito e, conseqüentemente, o que as leis naturais prescrevem. A partir do momento em

${ }^{13}$ Outras leis naturais que, para Hobbes, são princípios de filosofia política de sua própria visão de mundo: é preciso evitar a ingratidão, os insultos, o orgulho, enfim, tudo o que prejudicasse a concórdia; o mal deve ser vingado sem crueldade; os bens devem ser usados com moderação e ser distribuídos com eqüidade; havendo disputas, que se recorra a um árbitro imparcial; cumprir os pactos celebrados; gratidão pelos benefícios obtidos de outros; que cada um se esforce por acomodar-se com os outros; mútuo acordo ou complacência; facilidade para perdoar; que ninguém por atos, palavras, atitude ou gesto declare ódio ou desprezo pelo outro; que cada homem reconheça os outros como seus iguais por natureza; que, ao iniciarem-se as conduções de paz, ninguém pretenda reservar para si qualquer direito que não aceite seja também reservado para qualquer dos outros; se a alguém for confiado servir de juiz entre dois homens, que trate a ambos eqüitativamente; que as coisas que não podem ser divididas sejam gozadas em comum, se assim puder ser; e, se a quantidade da coisa o permitir, sem limite; caso contrário, proporcionalmente ao número daqueles que a ele têm direito; como há coisas que não podem ser divididas ou gozadas em comum, a equidade determina que o direito absoluto ao uso ou o direito a primeira posse - se 0 uso for alternado - seja determinado por sorteio, que poderá ser de duas formas: arbitrário - que é aquele com o qual todos os competidores concordaram - ou o natural - cuja primeira apropriação se dá pela primogenitura -; que a todos aqueles que servem de mediadores para a paz seja concedido salvo-conduto; que aqueles que entre os quais há controvérsia submetam seu direito ao julgamento de um árbitro; não fazer aos outros o que não gostaria que fizessem a si.

${ }^{14}$ Existem interpretações no sentido que o soberano permanece obrigado pela lei que fez enquanto não resolve ab-rogá-la. Nesta medida, seu poder absoluto não é po der arbitrário (CHEVALIER, 1973, p. 75) 
que cabe ao soberano determinar o conteúdo das leis naturais, será conforme à lei natural qualquer lei civil por ele ordenada. Volta-se, novamente à incongruência de o soberano ditar as leis, inclusive o conteúdo das leis naturais, a que ele mesmo teria que se sujeitar ${ }^{15}$.

Para Hobbes, a lei positiva - lei civil - dependente de um poder comum, de um poder soberano, é condição para o julgamento moral dos atos humanos e a valoração do justo depende da existência do Estado. Aí a influência de Hobbes para o positivismo jurídico. Por isso no estado de natureza não existe bem e mal, restando todas as ações à mercê de ajuizamentos éticos, devendo ser avaliadas tendo em vista o fim da auto-conservação. Já a moralidade é instaurada pelo estado civil em que há padrões objetivos de julgamento.

Mas no estado de natureza, em que não há justificação em leis positivas, Hobbes admite a existência de uma medida do bem e do mal que independe das leis positivas e que seria a justificação não objetiva - que não tem vista uma lei positiva - dada para a saída do estado de natureza e ingresso no estado civil. Neste estágio há que se avaliar o justo e injusto não pela ação - sob o ponto de vista da moral -, mas pelo propósito e pela consciência dos agentes - do ponto de vista da ética. "Assim, o estado de natureza não pode ser considerado como o estado em que não existem obrigações morais. Elas existem sim e sempre comandam em foro interno, conquanto não possam ter uma correspondência absoluta com as ações externas" (PAVÃO, 2000, p. 403). A moral de certo agrupamento pode perfeitamente não coincidir com os valores pessoais de cada indivíduo que faz parte desta. Por essa razão o Estado não cria as obrigações morais, mas cria circunstâncias que tornam intersubjetivamente possíveis as ações morais.

Além disso, prenunciando o liberalismo, Hobbes é a favor de boas leis, mas apenas de leis necessárias ao bem do povo - poucas leis. As leis não seriam feitas para constranger a

${ }^{15}$ Renato Janine Ribeiro (2006, p. 28-30) propõe a seguinte interpretação do contrato para a solução do antagonismo: apesar de Hobbes afirmar que somente é possível estabelecer o que é direito a partir da instituição do Estado enquanto poder punitivo, há pactos, dentre eles, o primeiro contrato, aquele que funda o Estado, que valem mesmo quando não há um poder estatal porque não haveria porque desconfiar não seria razoável e racional desconfiar - que poderiam ser violados pela outra parte, mesmo não existindo um poder coercitivo garantidor de si. Assim é o pacto que funda o Estado porque os pactuantes necessitam, para seu próprio bem, que seja cumprido, mesmo não havendo o Estado. Quando todos firmam o pacto pelo qual se institui o Estado, cada um dos indivíduos está cedendo algo no ato - o direito a todas as coisas, de que antes desfrutavam - e assim retira, de todos os outros a razão para suspeita recíproca. 0 contrato de todos com to dos faz com que cada qual ocupe as duas posições, a de quem desconfia a daquele de quem os outros deveriam desconfiar. Cada um cedendo de imediato, retira dos outros a razoabilidade de dele suspeitar. 0 caráter simultâneo da operação faz com que a guerra encontre fim (RIBEIRO, 2006, p. 31). 
existência dos homens, mas para dirigi-los, protegê-los contra si mesmos e contra os outros (CHEVALLIER, 1973, p. 76).

\section{Estado e a religião}

Também cabe ao soberano toda decisão em matéria religiosa, em virtude de a religião implicar a existência de um poder distinto da soberania civil, o que também originaria conflitos, só não devendo os súditos obedecer-lhe se ultrajasse a Deus ou adorasse um homem a quem conferisse atributos divinos. Um poder religioso autônomo é uma ameaça ao poder estatal, o qual preza tanto. O clero manejava consciências, opiniões que provocam ou não as revoltas, situações às quais Hobbes tinha aversão.

À primeira vista, teríamos então - como causa da revolta - um discurso errado da filosofia do direito ou da filosofia política. Contudo, uma leitura mais atenta do conjunto da obra (de Hobbes) demonstra que o descontentamento com o poder legítimo ${ }^{16}[\ldots]$ provém em última análise de um manejo das consciências por um sujeito oculto e oposto ao Estado". (RIBEIRO, 2006, p-. 25)

Neste sentido, a boa religião seria a religião civil, a religião do soberano, que não fosse construção da razão, mas da autoridade, que encarasse não a crença, mas a prática (CHEVALLIER, 1973, p. 78) com um clero subordinado ao soberano e com a maioria de traços de laicidade. Mas o poder mais forte não é o do soberano leigo, que pode impor a morte física, mas o da fé e da religião, que são mais eficazes e tem acesso ao divino.

O Leviatã é um monstro bíblico do velho testamento citado no livro de Jó, misto de dragão e serpente, que reinava sobre os filhos do orgulho, representado no desenho da capa da primeira edição, cuja ilustração traz um corpo constituído por inúmeras cabeças, empunhando os símbolos dos dois poderes, o civil e o religioso.

O Estado é um estado cristão composto de pessoas cristãs e regido por leis cristãs que se encontram nas escrituras, cujo direito de interpretação é transferido de cada cristão ao soberano no momento do pacto social. Em Hobbes, Estado e Igreja se equivalem, mas seu absolutismo não é sustentado pelo direito divino dos reis, mas por argumentos puramente racionais e positivos que colocam a autoridade do soberano sob o poder civil, não adstrito à autoridade da Igreja. (CHEVALLIER, 1973, p. 81)

\footnotetext{
${ }^{16}$ Que para Hobbes é o poder absoluto.
} 
0 que Hobbes faz é articular várias teses que circulavam nos meios religiosos do século XVII. Tratava-se de idéias heterodoxas, talvez heréticas em face dos poderes estabelecidos, mas que foram bastante veiculadas na Inglaterra da Revolução Civil. (RIBEIRO, 2006, p. 20)

Ao mesmo tempo Hobbes, antagonicamente, se antecipa aos resultados da Revolução Francesa, defendendo posições que posteriormente serviriam, ao mesmo tempo, de fundamentação da direita, centro e esquerda na França, recorte cuja aplicação política somente se dá a partir da distribuição dos deputados no recinto da Assembléia Constituinte - monarquistas à direita, pequenos e médios proprietários contestadores da monarquia ao centro e radicais não proprietários à esquerda: as concepções como a mortalidade da alma e não condenação eterna, mas morte definitiva ${ }^{17}$, o aproximam da esquerda, a defesa da ordem, segurança e paz, do centro e o monarquismo e o contrato de origem não divina da direita republicana.

\section{A representatividade da obra de Hobbes para seus contemporâneos}

Hobbes, ao conceber seu sistema político, estava pressionado pelo problema da unidade de poder de uma época de difíceis lutas em torno da configuração e autoridade do Estado recém estabelecido, o que o levou a não admitir alternativa à anarquia além da autoridade do soberano, pois acreditava que o estado da divisão permanente só poderia ser combatido por um poder absoluto, indivisível e irrevogável.

Já tangido pela transição medievo-modernidade, não admitia a salvação da Igreja, ao contrário, via nela um mal para o Estado. Estava convencido da exatidão de sua construção, apresentando a descrição de um Estado como a justificação de uma sociedade (política).

Não pode ser considerado nem um precursor do estado totalitário - que exige a justificação da "totalidade ética" de Hegel - nem um liberal, mas um conservador. Admite 0 direito de resistência no caso de ameaça à vida, valoriza o princípio da legalidade ${ }^{18}$, prefere

${ }^{17}$ O resultado dessa primeira orientação é que se não há condenação eterna, mas apenas a salvação eterna ou
então a morte definitiva, não se prejudica em nada a recompensa aos bons, mas se reduz, em larga
proporção, o castigo dos maus. Quem almeja a salvação da alma nada perde, mas quem teme a condenação
eterna pode abrir mão desse temor (RIBEIRO, 2006, p. 21). Dessa forma Hobbes não deixa de ser um
precursor da doutrina protestante e do "espírito do capitalismo" descrito posteriormente por Weber.
${ }^{18}$ Inclui-se no princípio da legalidade os paradigmas da positividade (a vontade de um terceiro - soberano,
assembléia representativa, segmento aristocrático ou tirano - se impõe para ordenação e regulação as

Revista de DiReITo PúBLICO, LONDRINA, V, 4, N. 2, P. 16-36, SET./ DEZ. 2009. 
um governo de poucas leis - claras e simples -, considera útil a liberdade econômica moderada - e o modelo jurídico do absolutismo, apesar de não o ter como foco, viabiliza a institucionalização da economia propiciando aos indivíduos o livre estabelecimento dos contratos e, por conseguinte, das relações econômicas como um todo -, mas seu ideal não é a liberdade - certamente aqui, a liberdade do indivíduo em relação ao Estado -, mas a autoridade. Entre 0 excesso de liberdade e 0 excesso de autoridade, jamais teve um mínimo de hesitação: teme o primeiro como o prior dos males. (BOBBIO, 1991, p. 60)

Além disso, o grande pilar do liberalismo é a propriedade privada. Enquanto Locke elevou a propriedade privada a direito natural e concebeu o Estado como uma associação de proprietário em defesa dos próprios bens, Hobbes não reconheceu a propriedade como um direito natural e afirmou que ela somente surge com o aparecimento do Estado e que seu único titular é o soberano. Ainda afirma que os cidadãos singulares não têm a propriedade absoluta das coisas sobre as quais têm a posse, já que a propriedade pertence apenas ao Estado e existe na medida e durante o tempo em que o Estado assim desejar.

Mas o diferencial entre o Estado absolutista e o Estado liberal é a dinâmica da normatização do poder público ou o regime jurídico de direito público. Enquanto no Estado absolutista o poder público mantinha-se limitado pela figura do soberano ou pelo aparato legal que servia à institucionalização de sua ação, no Estado Liberal há a normatização jurídico-constitucional do poder público, dispondo de direitos (públicos) oponíveis ao próprio soberano (garantias individuais), o que significa, de forma geral, que a legitimidade do direito não fica circunscrita à atividade monopolizadora da força exercida pelo Estado, devendo o mesmo estar integrado às atividades públicas reconhecidas constitucionalmente.

Não há que se negar que Hobbes foi o grande fundamentador do Estado absolutista que tem como base de sustentação, conseqüente do embate entre monarca e burguesia, 0 regime monárquico e o capitalismo nascente da burguesia, que reclamava garantias para sua liberdade e para o cumprimento dos contratos que celebrava.

relações sociais independentemente de interpretações da tradição ou da Igreja), universalidade viabilização de normas que organizam de acordo com princípios neutros do ponto de vista ético - e formalidade - a aplicação de sanções independe da intenção dos agentes, mas apenas dos comportamentos contrários à lei - que até hoje caracterizam o Direito. 


\section{Considerações finais}

Observa-se, então, a relação existente entre o capitalismo e o Estado M oderno - já verificada desde 0 advento do Absolutismo, quando o capital necessitava de concentração do poder político e delimitação da atuação estatal para implementar seu desenvolvimento.

Da mesma forma que se demonstrou salutar a criação da concepção do Estado Absolutista para o fortalecimento da burguesia e a tentativa de alguma garantia de liberdade de cumprimento dos contratos, à medida que se verifica o crescimento da classe burguesa, juntamente com ela desenvolve-se a insatisfação com as limitações impostas pelo soberano e a precariedade que sua vida e seus bens adquirem enquanto considerados meros súditos. A vida humana, a liberdade e a propriedade, principalmente vislumbrados sob o ponto de vista econômico, começam a ser exigidos como garantias legais, principalmente aquelas referentes aos contratos, com a garantia, mas não intromissão na autonomia privada.

Consoante essa nova concepção, preconizada pelo modelo Liberal, o Estado deveria garantir o mínimo para o desenvolvimento da sociedade, logo, a segurança do cidadão, segurança jurídica - precipuamente no referente ao cumprimento dos contratos - , o livre fluxo de mercadorias, enfim, intervir de maneira pontual unicamente quando a concorrência corre o risco de se tornar prejudicada.

\section{Referências}

ABRAGNANO, Nicola. Dicionário de Filosofia. Trad. Ivone Castilho Benedetti. 4. ed. São Paulo: Martins Fontes, 2000.

BOBBIO, Norberto. Thomas Hobbes. Rio de Janeiro: Campus, 1991.

CHEVALLIER, Jean-Jacques. As Grandes Obras Políticas: de M aquiavel a nossos dias. Trad. Lydia Christina. 3. ed. Rio de Janeiro: Agir, 1973.

HOBBES, Thomas. Leviatã ou Matéria, Forma e Poder de um Estado Eclesiástico e Civil. Trad. João Paulo Monteiro e M aria Beatriz Nizza da Silva. 2. ed. São Paulo: Abril Cultural (Os Pensadores), 1979.

PAVÃO, Aguinaldo. Considerações sobre o Capítulo XIII do Leviatã de Hobbes. Crítica, Londrina, v. 5, n. 20, p. 389-415, jul./set. 2000.

POUSADELA, Inês M . O Contratualismo Hobbesiano [ou de como para entender do direito é necessário pensar do avesso ]. In: BORON, Atílio A. (Org.) Filosofia Política Moderna: de 
Hobbes a Marx. São Paulo: Depto. de Ciência Política - FFLCH - Universidade de São Paulo, 2006.

RIBEIRO, Renato Janine. Thomas Hobbes, ou: A Paz contra o Clero. In: BORON, Atílio A. (Org.) Filosofia Política Moderna: de Hobbes a M arx. São Paulo: Depto. de Ciência Política - FFLCH - Universidade de São Paulo, 2006. 